\title{
The Human Papillomavirus (HPV) in Human Pathology: Description, Pathogenesis, Oncogenic Role, Epidemiology and Detection Techniques
}

\author{
A. Alba ${ }^{*}, 1$, M. Cararach ${ }^{2}$ and C. Rodríguez-Cerdeira ${ }^{3}$ \\ ${ }^{I}$ Spanish Society of Cervical Pathology and Colposcopy \& Centre for Molecular and Cellular Studies, Lugo, Spain \\ ${ }^{2}$ Spanish Society of Cervical Pathology and Colposcopy, Barcelona, Spain \\ ${ }^{3}$ Department of Dermatology, CHUVI \& University of Vigo, Vigo, Spain
}

\begin{abstract}
Persistent infection by human papilloma virus (HPV) is considered to be the main causative agent of cervical cancer and other anogenital cancers. Of more than 30 genotypes capable of infecting the anogenital tract it is estimated that, worldwide, HPV 16 and 18 cause 70 percent of the cervical cancers. So far, more than 100 types and subtypes of HPVs have been wholly or partially sequenced. All of them, approximately 40 types, have been isolated from lesions to the lower genital tract and between 15 and 20, according to different studies, have been detected in carcinomas. According to their oncogenic risk, they are classified as low-risk HPV (LR-HPV) and high-risk HPV (HR-HPV). We must take into account that certain viral types may appear in cancerous lesions as a result of a co-infection and not be the causative etiologic agents for tumour transformation. As is logical, epidemiological studies attribute important population variations to the prevalence and cause/effect of different viral types, however, there is no doubt about the high prevalence or involvement of types 16 and 18 in high level pathologies and carcinomas in our population.

The detection of HPV DNA through techniques of Molecular Biology, regardless of the method used, are based on the specificity of the complementarity among the nucleic acids. A DNA sequence has the ability to specifically hybridise with other DNAs or RNAs so specifically that at a certain temperature they only form hybrids if 100 percent of the bases are complementary. The way of detecting these hybrids, the composition of the DNA probes, and the existence or not of amplification of the signal mark the difference between the different detection techniques. The assessment of the viral load, integration, and other molecular parameters are shaping up as excellent complementary diagnoses in daily clinical practice.
\end{abstract}

\section{INTRODUCTION}

The papillomavirus (PV) are small virus with DNA from the family Papovaviridae that infect a wide variety of vertebrates including man. They measure $50 \mathrm{~nm}$ in diameter, lack a membrane, and their capsids have an icosahedral form composed of 72 capsomeres.

Despite their wide distribution, they show a high degree of cellular tropism i.e. they only infect dried epithelium (skin) and mucous membranes (oral and genital) inducing the formation of benign lesions (warts or papillomas), and under certain conditions and in partnership with certain cofactors [1] they can produce carcinomas.

Harald zur Hausen, in 1976 [2] was the first to report and study the HPV and its participation in carcinogenesis, subsequently, in several epidemiological and molecular clinical studies, they were established as the main causative agent of cervical cancer. Later it was demonstrated that virtually all women with cervical carcinoma were infected with some kind of HPV $[3,4]$.

*Address correspondence to this author at the Spanish Society of Cervical Pathology and Colposcopy \& Centre for Molecular and Cellular Studies, Lugo, Spain; Tel: 0034639882446; Fax: 0034982284183;

E-mail: alfonsoalba@e-icm.net

\section{CLASSIFICATION OF HUMAN PAPILLOMAVIRUS}

Historically, the PV have been grouped together with the polyomavirus to form the family Papovaviridae, this term derives from the first two letters of the first virus group (rabbit papillomavirus, mouse polyomavirus, and simian vacuolating). The PV and polyomavirus can be easily distinguished by differences in the size of the virions $(55 \mathrm{~nm}$ and $40 \mathrm{~nm}$ ) and in the genome ( $8 \mathrm{kp}$ and $5 \mathrm{kp}$ ), respectively. In addition, the DNA of these two subfamilies does not hybridise and have different antigenic characteristics. Thus, they are currently being considered as individual subfamilies of the Papovaviridae. The classification of the types of PV is based on the kind of origin and the degree of homogeneity of DNA. More than 100 types have been reported in humans, in cattle 6 types, in dogs 2 , in rabbits 2 , in horses, chimpanzee, and macaco only one type. In addition, they have also been identified in poultry and fish [5].

According to the malignancy of injuries that occur, they are classified as: low-risk virus that produce benign lesions (primarily types 6 and 11 in condylomatose injuries together with types $40,42,43,44,54,61,70,72$, and 81) and highrisk viruses that cause precancerous lesions and cancer (HPV types $16,18,31,33,35,39,45,51,52,56,58,59,68,73$, and 82) [6]. 


\section{STRUCTURE OF THE VIRAL GENOME}

The DNA of HPV is circular, double chain, and contains approximately 8000 base pairs (bp). Its genome can be divided into three areas: The long control region (LCR), the early region $(\mathrm{E}=$ Early), and the late region $(\mathrm{L}=$ Late) (Fig. 1) $[7]$.

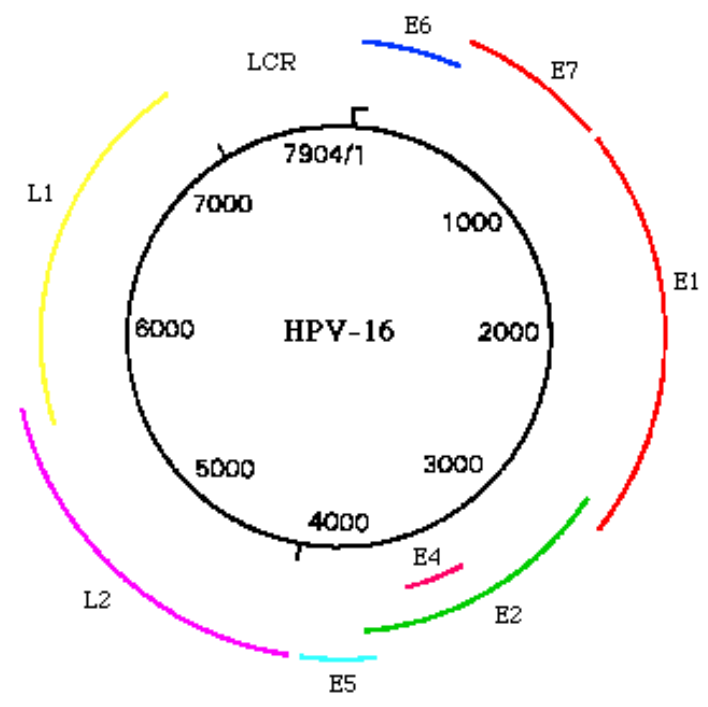

Fig. (1). Genetic map of Human Papillomavirus type 16.

The LCR region corresponds to 15 percent of viral genome and contains the promoters, which initiate replication and control transcription. This region is divided into two main domains: RE2, regulated by the presence of the viral protein E2 and where the origin of replication of viral DNA is located, the early promoter; and the EC (cellular enhancer) domain, a strong transcription potentiator that exclusively depends on cellular transcriptional factors. The early promoter is found in the RE2 domain, from which oncogenes E6 and E7 are transcribed. In this domain, the origin of replication of viral DNA, dependent on the presence of the viral protein E1 and E2 has been described [7].

The tissue specificity of the HPV lies in the CE, where the joint participation of cellular factors promote the activity of the early promoter exclusively in cells of epithelial origin. The early region $(E=$ Early) represents 45 percent of the genome and contains 7 regions of open reading, which encode for non-structural proteins, whose function is to control the replication of DNA and induce malignant transformation of the host cell: E1 controls the replication of episomal DNA, through the codification of a modulator (E1$\mathrm{M}$ ), and of a replication factor (E1-R). While this area of the genome is complete and functional, it produces normal replication, avoiding the integration of DNA into the genome of the cell. It is believed that the E2 protein plays a very important role in the life cycle as it has the capacity to suppress or activate the viral promoters. It encodes a repressive transcriptional factor (E2-TR) that inhibits the transcription of the promoter $\mathrm{P} 97$, which controls the synthesis of E6 and E7. The protein product is still not known as is the role of E3. E4 produces proteins involved in the maturation of the viral particles. It is believed that this protein initiates coilocytotic changes in epithelial cells. This gene is lost when it integrates the viral DNA into the genome of the cell. E5 produces a small protein of 44 amino acids that joins the cytoplasmic membrane. Loss or mutation of this region avoids episomal DNA replication and favours the integration of DNA into the chromosome. The E6 and E7 regions produce two transforming oncoproteins. The late region (L) corresponds to 40 per cent of the genome and contains two genes that encode for structural proteins from the capsid: L1, produces a protein of $54,000 \mathrm{~d}$ which is produced in a greater quantity, and which is highly conserved among different types of HPV, and $\mathbf{L 2}$ that produces a lesser amount of protein, and is specific for each viral type [8].

\section{INFECTION MECHANISM}

In order for the HPV to be able to penetrate and initiate an infectious process requires a continuity of tissues, so that the virus can be in contact with the permissive cells, which are the basal cells of the epithelium. Once they have infected the target cells, viral replication in the spinous layer starts. The assembly of the virions is carried out in the upper strata of the epithelium when the cells have been differentiated (granular cells), since this is a prerequisite for this maturity event and cell differentiation. Finally, in the squamous cells the virions are expelled and may start a new infection cycle [9].

In works that attempt to explain the model of high-risk HPV infection, using virus-like particles, it has been shown that during sexual activity, micro-trauma of the genital epithelium, particularly in the transformation areas of the cervical epithelium, allows exposure of the basal cells to active proliferation of the various types of HPV, allowing union between the receptor of the basal cells with the protein from the viral capsid L1. Once the virus is joined to the cell surface, it beds into the host cell cytoplasm, a process that has been identified as endocytosis [10]. Two systems have been recognised: the first involves a protein complex called Clathrin [11], used by types 16 and 18, the second, uses a group of proteins, mainly Caveolin, called endocytosis by caveolae, involving HPV 31 [12]. It is possible to define a non-productive viral population, located in the basal layer, in which low level viral DNA replication is maintained (30-50 copies per infected cell), in extrachromasomal form, called episomes, which are structured on the histone base and genetic material [13-15]. It is postulated that during this stage, it is ensured that the viral DNA is diffusely distributed by basal proliferating cells and that on maintaining a small number of copies it prevents the activation of the immune response [16]. The proliferating basal cells migrate to the parabasal strata and strata spinosum, amplifying the expression of early viral genes through the non-encoding region (NER), which allows DNA to produce hundreds of copies per cell [17]; this stage in the viral cycle is known as the proliferative or productive phase [18]. It is possible that during this stage of amplification of the viral genome, the inhibition of oncoproteins E6 and E7, damage to the cytoskeleton, mitochondrial energy disorder, and apoptosis allow for greater spread of the viral progeny, provided that 
the proteins in the viral capsid (L1 and L2) have been synthesized, forming new infectious virions with the viral DNA.

E6 is a 150 amino acid protein that binds zinc, forms a complex with p53 and the enzyme ubiquitin ligase, producing its degradation [19]. The p53 gene is located on chromosome 17; protein p53 in basal conditions, allows stopping the cell cycle in phase G1, an effect mediated by the protein $\mathrm{p} 21 \mathrm{cip} 1 / \mathrm{WAF} 1$, which inhibits the cyclindependent kinases or activates the mechanism of apoptosis through the activation of the bax gene, processes which are triggered off by a high viral load or by cellular DNA mutations. In this way, their protective function of the cellular genome is altered by protein E6. Other functions correspond to the amplification of the activity of telomerase, induce mutated DNA synthesis and increase the integration of viral DNA into host cell [20].

A protein called tuberine, $200 \mathrm{Kda}$, generated from a tumour gene suppressor known as a complex of tuberous sclerosis (TSC type 2) has recently been described. Tuberine controls cell proliferation through the inhibition of the protein kinase S6. E6 binds to tuberine, inhibits its function. The interaction of E6 with Rap-1 allowing activation of the MAP kinase system. The interaction of E6 with membrane proteins known as counterparts of guanylate cyclase (MAGI 2 and 3) has also been described. These proteins in normal conditions stimulate PTEN (counterpart of phosphatase and tensine) which, in basal conditions, controls cell growth inhibiting the system via blocking the Akt and transforming PIP3 to PIP2 [21]. On degradation of MAGI 2 and 3, by the action of E6, the regulatory effect on cell growth is lost (Fig. 2).

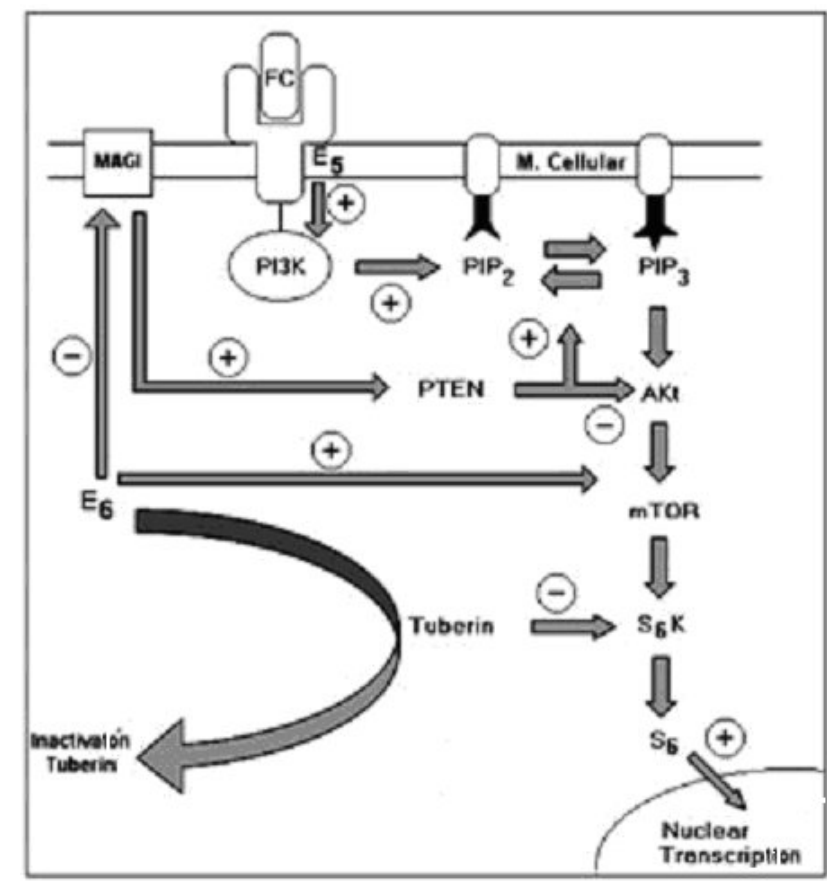

Fig. (2). Protein kinase system activated by mitogen (MAP kinase). Stimulation of the track for growth factor (GF), E5 and E6 leads to the transcription of genes related to cell proliferation. Blockage of PTEN and Tuberine by E6 maintains the system activated.
E7 is a 100 amino acid zinc binding protein, which undergoes phosphorylation, allowing binding through its end N-terminal (amino acids 20-30), to the protein retinoblastoma $(\mathrm{pRB})$, altering its role. $\mathrm{PRB}$ originates from the gene located on chromosome 13 interacts with the E2F cellular transcription factor at the G1 cell cycle stage inhibiting the expression of genes related to the replication of DNA and cell proliferation [20]. In this way, binding of E7 with $p R B$, through the phosphorylation of the latter, allows the expression of thymidine kinase, c-myc, polymerase to, PCNA, Ki-67, mini-chromosome maintenance protein (MCM), p16, cycline A and E [22, 23].

Other functions described for the E7 protein relate to the binding with Kinase of Histone $\mathrm{H1}$, which favours cellular transformation [20]. In addition, E7 inhibits the p16ink4A protein, which in basal conditions slows down cellular multiplication [19]. Its mutagenic effect, producer of aneuploidy and facilitator of the integration of viral genome to host cells [20] is also mentioned. In this way, the oncoproteins E6 and E7 favour the proliferation and immortality of cells with a greater mutated DNA load (Fig. 3).

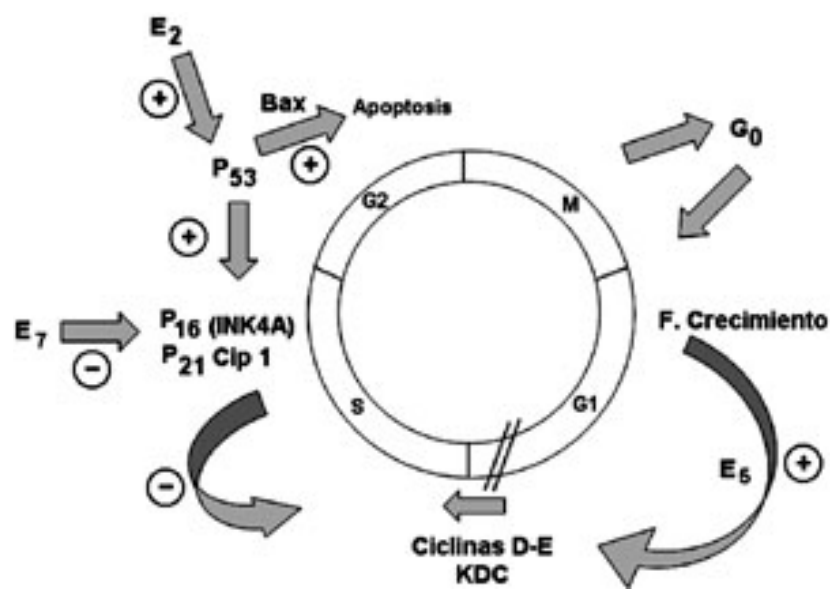

Fig. (3). Scheme regulating the cell cycle by E2, E5, E7 and p53 via cyclins and cyclin-dependent kinases (CDK). P53 activated by E2 leads to apoptosis (via Bax gene) or blockage of the cell cycle in $\mathrm{G} 1$ (via P16 - P21). E7 stimulates the role of cyclins D-E/CDK, leading to uncontrolled cell proliferation, an effect shared by E5.

\section{ONCOGENIC MECHANISM}

The epithelial cells, on being infected, activate their cellular defence mechanism consisting of a revision of the DNA sequence before division. This review process occurs during a phase of the cell cycle and is headed by a cascade of proteins, which highlights $\mathrm{p} 53$ and protein $\mathrm{Rb}$. When the cell locates the viral DNA, in a perfectly regulated process, it attempts to repair the error and given that this DNA is too big to be eliminated, p53 and Rb lead the infected cell to "programmed cell death" by apoptosis, thus, avoiding that this cell could serve as an infection propagator. The high-risk types of HPV are protected from this cellular mechanism and are able to synthesise proteins, which block this cellular defence system. The ORFs E6 and E7, transcribe a product whose translation results in the production of proteins of the same name (E6 and E7) that will be able to block the p53 and $\mathrm{Rb}$ cell cycle and protect from cellular death by 

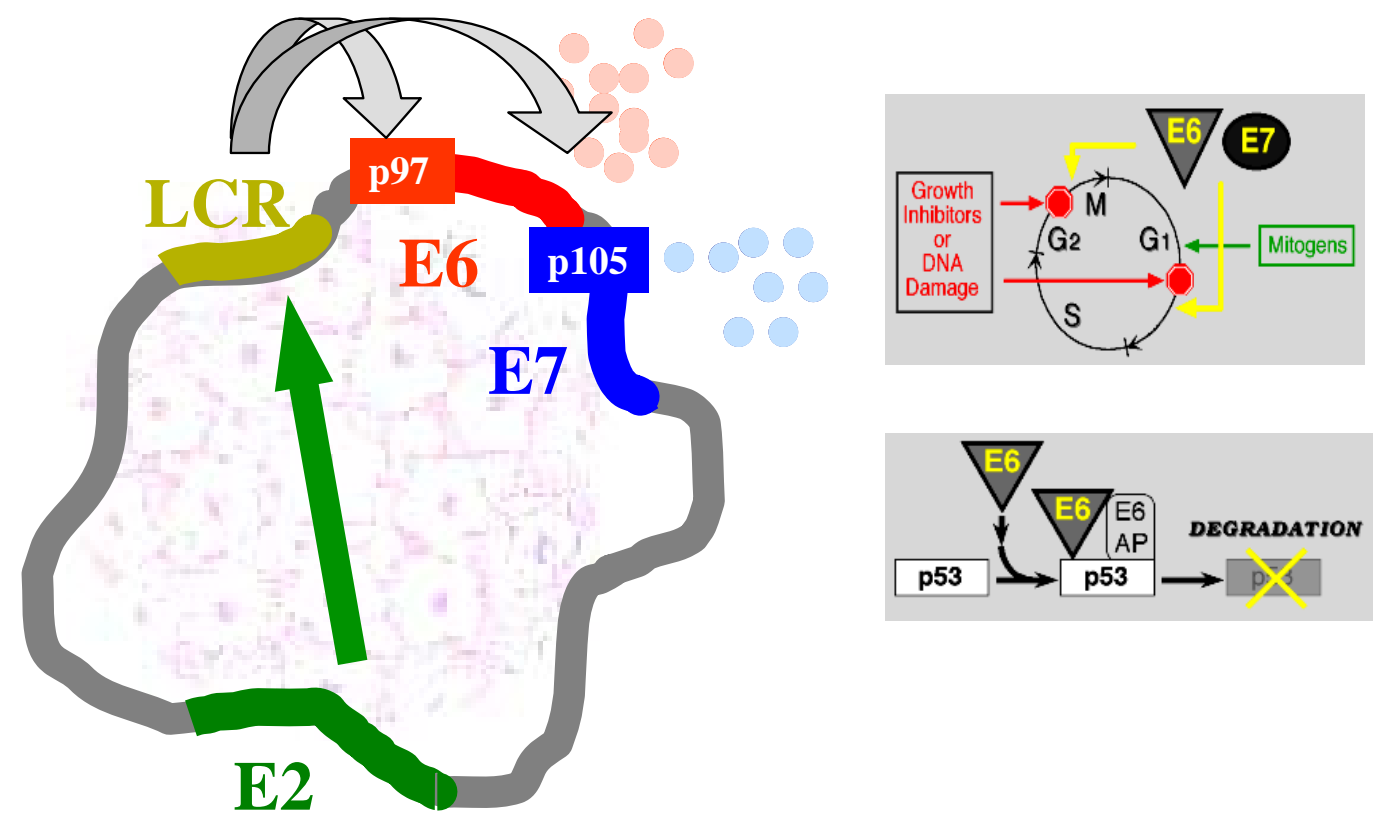

Fig. (4). Interaction between the viral protein and the cell cycle.

apoptosis, respectively, and can, thus, continue to be used as a centre for production of particular viral oncogenes. Thus, E6 and E7 should be considered, to all extents and purposes, as viral oncogenes [24].

The process of blocking of p53 and Rb protein E6 and E7, would pose few problems if it did not lead to cell immortalisation. As a result of the blockage of the error system, the cell not only is unable to eliminate the viral DNA, but also is unable to fix intrinsic errors in the cellular DNA, so that it accumulates genetic alterations and in addition, cannot "die" since the process of apoptosis has also been blocked, it would become an immortalised cell with DNA in progressive decline, or what is equivalent to, a cell with a neoplastic phenotype (Fig. 4).

It seems clear, in view of these processes, that the mechanism of carcinogenicity by HPV begins with the expression of E6 and E7 that block p53 and Rb and that immortalise the compromised cell, and thereby, the functionality of their DNA, nevertheless, certain experiments have shown that the baseline E6 and E7 expression in HPVs is very low since the E2 protein, through the URR regulatory region remains virtually silenced (Fig. 5). In view of this, it seems clear that only an infection with large amounts of virus would be capable of producing enough units of E6 and E7 to start this process. Indeed, infections with high viral load, in which the immune system is not competent to eliminate the infection, have a higher risk of neoplastic transformation. However, it has been demonstrated that certain persistent infections with low viral load, generate an effective tumour phenotype, so we may know what the mechanism of immortalisation with such a low viral load is. The demonstration that in most of the carcinomas the viral DNA was fragmented and integrated into the cellular genome answered this question. In most cases, a portion of the virus, fragments in the E2 region (Fig. 8) losing its ability to act on URR and give the command to maintain the expression of E6 and E7 repressed, thus, a small amount of virus will be deregulated and produce copious amounts of E6 and E7 protein, which begins the process of blocking of $\mathrm{p} 53$ and $\mathrm{Rb}$ so effectively.

The integration of viral genome to that of the host cell does not occur in all cases of cervical cancer, and may be explained by mutations in repressive areas, such as the region Ying-Yang (YYI), which would maintain the continued expression of E6 and E7 or by the production of more stable "chimeric" RNA, permitting greater synthesis of these oncoproteins [25].

The previously described processes allow uncontrolled cellular proliferation with a greater load of mutations. Malignant transformation requires, in addition, the expression (mutations) of a set of genes responsible for allowing the release of neoplastic cells, invading nearby tissues, facilitating angiogenesis, evading the immune response, provoking metastasis among other functions [26]. In this sense, there is evidence of the participation of mutations in the $3 p 14.2$ region (fragile histidine gen), induced in part by the integration of viral genome (HPV 16), in addition to those in the chromosomal regions, 3p22.2, $11 \mathrm{q} 22.1$, and $11 \mathrm{q} 23.3$ that have been associated with persistence of intraepithelial lesions and/or progression to cervical cancer $[27,28]$.

\section{EPIDEMIOLOGY HUMAN PAPILLOMAVIRUS INFECTION}

HPV infection is transmitted by direct contact between the skin and mucous membranes, with sexual relationships being the main form of contact, although there are others such as those which occur between mother and child at the time of childbirth. Moisture and rubbing favour transmission. Transmission through objects, such as surgical material, clothes, and fomites in general, seems to be a reality. However, for infection to develop, complete virus must be transmitted and not only DNA 


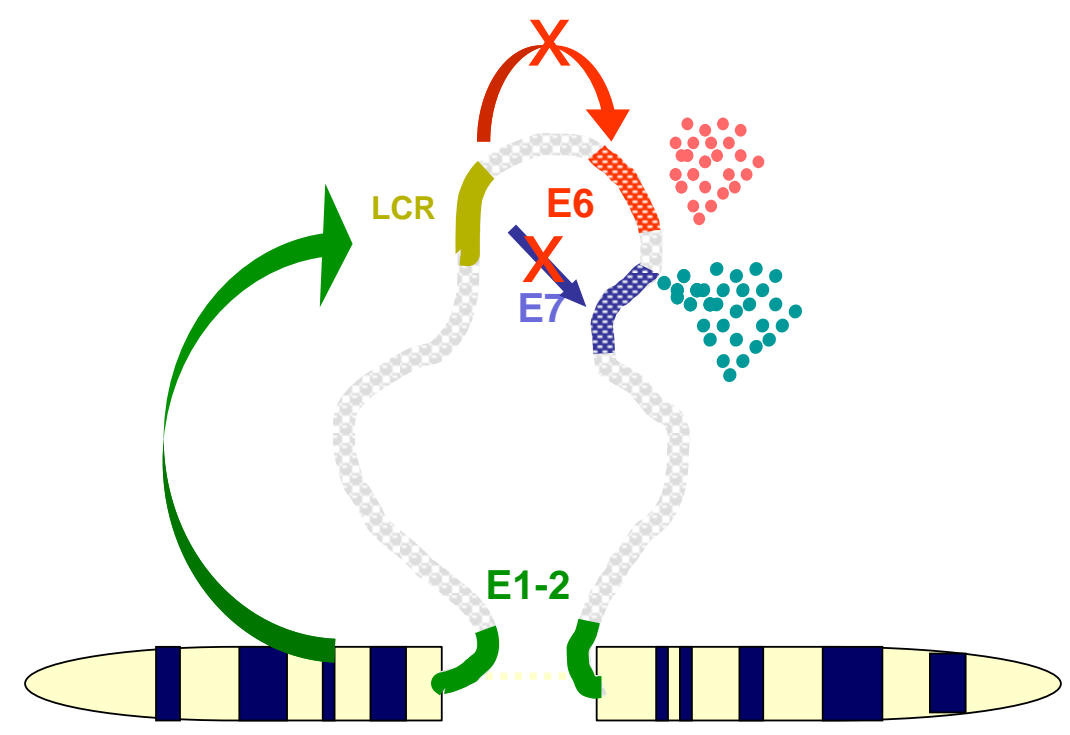

Fig. (5). Integration of HPV in the host genome.

fragments. It is estimated that, in sexually active populations, the virus is ubiquitous, infecting more than 80 percent of the women of reproductive age. However, 80 per cent of infections are transitory and removed from the immune system without leaving injury. There are 20 percent, which may progress to form precursors of genital cancers. The incidence and prevalence of HPV infections in the general population are very diverse, there are studies which are very well defined. A significant number of variables are being found, such as the type of diagnostic test carried out as there is no general homogenization of method and the test sensitivities, style and quality of life of the study population, cofactors affecting it and of course the natural history of the disease varies (Tables 1, 2).

HPV 6 and 11 are incidentally linked with 90 percent of genital warts. One of every ten sexually active people suffers an episode of genital warts during their life. In Spain, the incidence of episodes of genital warts is estimated at 182 cases per 100,000 persons/year, corresponding to 56,446 cases annually in the 14 to 64 year-old general population, including 24,613 in women [29, 30].
Cervical infection by some kind of HPV is relatively common in sexually active women, (it is estimated that it affects 80 percent of women at some time during their lives). However, most of these infections are sub-clinical transitional and a spontaneous clearance in the infection occurs after $12-30$ months in 70-90\% of infected women.

It is estimated that among sexually active women more than 70 percent have been infected by one or more types of HPV by what constitutes the most frequent sexually transmitted infection in the world [31].

Thus, HPV infection can be expressed in the clinical, sub-clinical or latent form. Recent data suggest that the prevalence of the sub-clinical infection can reach 40 percent in women in times of greater sexual activity, reducing considerably from 30 years-old. In Spain, the prevalence of infection (positivity to the HPV DNA) is 3-6 percent 2 percent for low grade lesions, and a 0.05 percent for the high-grade. In recent years, we have seen a significant increase in the prevalence of HPV infection, both in its clinical forms or as condylomata acumianta, and in its forms

Table 1. Types of Human Papiloma Virus (HPV) and their Effects on Various Pathologies

\begin{tabular}{|l|c|c|c|}
\hline \multicolumn{2}{|c|}{ Type of Lesion } & Most Frequent HPV & Least Frequent HPV \\
\hline \hline \multirow{3}{*}{ Skin warts } & Plantar & 1,2 & $4,6,3$ \\
\cline { 2 - 4 } & Vulgaris & $1,2,7,10$ & $4,7,26,28,29,41,57,60,65$ \\
\cline { 2 - 4 } & Plana & 3,10 & $2,26,27,28,29,38,41,49$ \\
\cline { 2 - 4 } & In transplant receptor & & $1-6,8,10,12,15,16,17$ \\
\hline Verruciform epidermodysplasia & $5,8,17,20$ & $9,12,14,15,19,21-25,36-38,46,47,50$ \\
\hline \multirow{2}{*}{$\begin{array}{l}\text { Anogenital } \\
\text { lesions }\end{array}$} & Condylomata acuminata & 6,11 & $2,16,30,40,41,42,44,45,54,55,61$ \\
\cline { 2 - 4 } & CIN, VAIN, VIN, AIN, PIN & $6,11,16,18,31$ & $30,34,33,35,39,40,51,42-45,52,56-59,61,62,64,66,67,69$ \\
\hline
\end{tabular}

CIN: Cervical intraepithelial neoplasia.

VAIN: Vaginal intraepithelial neoplasia.

VIN: Vulvar intraepithelial neoplasia.

AIN: Anal intraepithelial neoplasia.

PIN: Penile intraepithelial neoplasia. 
Table 2. Viral Types of Human Papilloma Virus (HPV) Associated with Invasive Carcinoma

\begin{tabular}{|c|c|c|c|}
\hline \multicolumn{2}{|c|}{ Type of Lesions } & Most Frequent Lesions & Least Frequent Lesions \\
\hline \hline \multirow{3}{*}{ Benign pathology of the cervix } & Oral papilloma & $2,6,11,16$ & 7 \\
\cline { 2 - 4 } & Laryngeal papillomatosis & 6,11 & \\
\cline { 2 - 4 } & Conjunctive papilloma & 6,11 & 16 \\
\cline { 2 - 4 } & Nasal papilloma & Under study & $6,11,57$ \\
\hline
\end{tabular}

\begin{tabular}{|c|c|c|c|}
\hline \multicolumn{1}{|c|}{ Types of carcinoma } & Most frequent HPV & Least frequent HPV \\
\hline \hline \multirow{5}{*}{ Carcinomas } & Cervical carcinoma & $16,18,31,45$ & $\begin{array}{c}6,10,11,26,33,35,39,51,52,55,56,58,59, \\
66,68,73 ? \text { and other unclassified }\end{array}$ \\
\cline { 2 - 4 } & Vulvar, vaginal, anal and penile carcinoma & 16,18 & $11,31,33,35,39,45,51,52,56,58,66$ \\
\cline { 2 - 4 } & Basal and squamous cell carcinomas & $2,3,5,8,9,10,17$ & $12,14,15,17,19,20,21-25,36-38,47,50$ \\
\cline { 2 - 4 } & Amygdala cancer & 16 & 18,33 \\
\cline { 2 - 4 } & Oropharyngeal & 16 & $3,6,11,18,33,57$ \\
\cline { 2 - 4 } & Laryngeal cancer & 16 & $6,11,18,35$ \\
\cline { 2 - 4 } & Oesophageal cancer & 16,18 & 6,11 \\
\cline { 2 - 4 } & Mammary cancer (intraductal invasive) & & Probably 33 \\
\cline { 2 - 4 } & Prostate cancer & 16,18 & Under study \\
\cline { 2 - 4 } & Urethral cancer & $5,8,16$ & $14,17,20,47$ \\
\hline
\end{tabular}

of sub-clinical expression, identifiable by cytological changes, colposcopy and/or vulvoscopy and/or vaginoscopy, and finally peniscopy together with urethroscopy. The clinical forms, usually caused by low-risk oncogenic HPV types (6-11), tend to be benign. The sub-clinical forms may include both benign lesions as injuries with premalignant potential, and tend to be caused by high-risk oncogenic HPV types (16-18). HPV infection-16 is the most prevalent in European women. Finally, great heterogeneity with regard to the HPV types of the groups studied was revealed [32-34].

HPV is a necessary cause but not enough for the development of a cervical cancer. HPV is responsible for the $100 \%$ of the cervical, squamous or glandular cancers; there is no possibility of development of a cervical cancer in the absence of HPV. In addition, it is incidentally related with 90 percent of anal canal cancers, 40 per cent of vulvar and penile cancers, and 12 percent of cancers of the oropharynx. Its relationship with other cancers (non-melanoma skin, retinoblastoma, etc.) is being investigated.

An increased prevalence of HR-HPV types 16, 18, 31, $33,35,45,51,52,58,59$ is found in Africa and Latin America. HPV 16 is the most common in the world, except Indonesia and Algeria, where HPV 18 is the most common. HPV 45 shows high frequency in West Africa types 33, 39, and 59 are concentrated in Central and South America.

In men, the limited data on prevalence and natural history of HPV indicate that the average prevalence accumulated over the life in heterosexual men between 18 and 44 yearsold ranges between 56 and 65 percent, with 26 - 50 percent for the HR-HPV. Homosexuals and bisexuals have higher prevalences. The most prevalent are 16, 31, 51 and 84 . The average duration of the infection is 4-5 months, this being equal for both HR and LR viruses. The epithelium of the penis, without conflicting epithelium/epithelium zones as in the cervix, is less receptive to infection. Multiple infection and location in balanoid fold/preputial are variables, which are positively linked to persistence.

Although the prevalence of HPV DNA in the genital tract of men seems to be similar to that observed in the uterine cervix of the same population and age group, the presence of HPV in the male genital tract generally produces latent subclinical infections, which can be detected only after the application of acetic acid. Due to these diagnostic difficulties and to the fact that male genital HPV infections have generally limited pathological consequences for healthy men, the majority of male HPV infections usually escape clinical observation.

It is known that the risk of infection is associated with sexual activity. Epidemiological studies have shown that more than one half of male partners of women with cervical intraepithelial neoplasia (CIN) presented penile lesions. It follows that the sex partners of men infected with HPV have increased the risk of having a genital cancer. Anyway, there are not enough studies to establish the biology and the dynamics of sexual transmission. The few studies on sexual partners of women infected by HPV-associated diseases generally include both symptomatic and asymptomatic men and fail to take into account any possible geographical or ethnic differences, known to be of importance in the prevalence of HPV and in the distribution of certain genotypes. In fact, the potential of large numbers of asymptomatic virus carriers may exist. Therefore, a man may considerably increase the risk that his sexual partner 
becomes infected and develops lesions, which prolong the infection in the couple [35-37].

As has been observed by Rodriguez-Cerdeira et al. [38], both vulvar intraepithelial neoplasia (VIN) and penile intraepithelial neoplasia (PIN) have considerably increased in recent years, especially in young men, due to greater exposure to the HPV, by changes in sexual behaviour. Also, the increase is due to greater agility and sensitivity of the diagnostic methods that lead to better and faster early diagnosis. Other associated cofactors reflected in the literature are the number of sexual partners and tobacco use, which would doubly act, on the one hand, transforming the cells immortalised by HPV-16, and, on the other, inhibiting apoptosis, and the genetic conditioners. Another associated cofactor is having suffered a sexually transmitted infection (STI) in the past. In addition, immunosupressed patients' neoplasms of the low genital tract (LGT) have a greater tendency to progress and relapse [38].

Untreated HR-PIN can evolve into invasive carcinoma. Squamous cell carcinoma or carcinoma of the penis constitutes more than 1 percent of all the malignancies in men in developed countries, and from 10 to 20 percent in underdeveloped. It has an incidence of 0.3-1 per 100,000 men. Its diagnosis is usually done in the sixth and seventh decades of life, with a peak of prevalence between 40 and 70 years-old. It is rare in people circumcised during the neonatal period [38].

\section{MOLECULAR DIAGNOSIS METHODS FOR HPV INFECTION}

The detection of HPV DNA through Molecular Biology techniques, regardless of the method used, is based on the specificity of the complementarity between the nucleic acids. A DNA sequence has the ability to hybridise with other DNAs or RNAs so specifically that at a certain temperature it only forms hybrids if 100 percent of the bases are complementary. The way of detecting these hybrids, the composition of the DNA probes and the existence or not of signal amplification mark the differences between the different detection techniques.

\section{HYBRIDISATION SOLUTION: HYBRID CAPTURE}

This method uses RNA probes that have the capacity to hybridise with the viral DNA in solution and be detected by luminescent methods. The modern commercial methods, such as the so-called Hybrid Capture II, unlike the previous versions that were regarded as suboptimal, have an adequate relationship between sensitivity and specificity if limits of luminous signal are imposed. The use of a cocktail of highrisk probes, that in the latest version includes 13 types and another for the group of low-risk, which includes 5 types, allows the detection of DNA of these viral types. It has the advantage of the possibility to semi-quantify the viral load, although this quantification only indicates number of viral copies and cannot be corrected as a function of the number of cells obtained in the samples. The main disadvantage is that it is neither able to distinguish between different viral types nor the presence of multiple infections and several studies cite non-specificities due to cross-reaction between the high-risk probes and certain low risk viral types [39].

\section{SYSTEMS BASED ON POLYMERASE CHAIN REACTION (PCR)}

Like hybrid capture, PCR uses small DNA probes that trace specific sequences of viral DNA and are called primers. The fundamental difference with the other techniques is in the chain amplification in the region of interest, which can then be visualised by different techniques (ELISA, electrophoresis, laser detection, etc.) with great effectiveness. In this method, firstly the specificity of the union of the two "primers" and, secondly, the sensitivity that results from the amplification process are combined (real detection of 10 copies of viral DNA in 1 million cells).

\section{PCR CONSENSUS AND SPECIFIC PCR}

There are two fundamental alternatives for detection of HPV based on conventional PCR. Firstly, and as the most frequently used method, we count on PCR of consensus regions, where a region with sequences, which are very similar among all the HPVs, is amplified, and then by methods of specific hybridization, enzymatic or of DNA sequencing, make specific typing of the virus possible. The most popular consensus method uses the common region L1, using MY09 and MY11 "primers". The amplified region generated is approximately 450 pairs of bases but has certain disadvantages, such as not allowing the detection of type 35 . For this reason, new "primers", such as PGMY09/11, were synthesized with a relative increase in sensitivity and spectrum of viral detection, and others such as GP5/GP6 or its improved variant GP5+/GP6+ [40-42].

Specific PCR is based on the design of "primers" for specific viral types, subtypes or variants and allows us to adjust the conditions of the reaction to femtogram sensibilities, with specificity of around 100 per cent. Moreover, it allows the realisation of analysis of viral integration, detection of variants, standardised quantification versus constitutional genes, etc. (viral load relative to the number of cells).

\section{DNA SEQUENCING}

DNA sequencing i.e. the obtaining of the sequence of nucleotides that shapes a particular region of viral DNA, is undoubtedly the reference standard for any of the previous techniques. Through this method can amplify or clone any fragment of viral DNA and determine their nucleotide composition, and compare the result with the database of all the known sequences of HPVs to determine to what type, subtype or variant the sample belongs. Its main drawback is the cost and the need for sophisticated laboratories to be able to use this methodology. The advantage, apart from giving direct and unequivocal typing, is to distinguish viral variants and polymorphisms, which are currently being considered as highly important risk variables in neoplastic transformation in addition to the presence of new viral types (Fig. 6).

\section{CLINICAL UTILITY}

Numerous studies have established the limits of sensitivity and specificity of each one of the techniques and variants described. As is the case with cytology, the quality of the DNA analysis is conditioned by a series of technical and conservational factors of the samples that at times are 


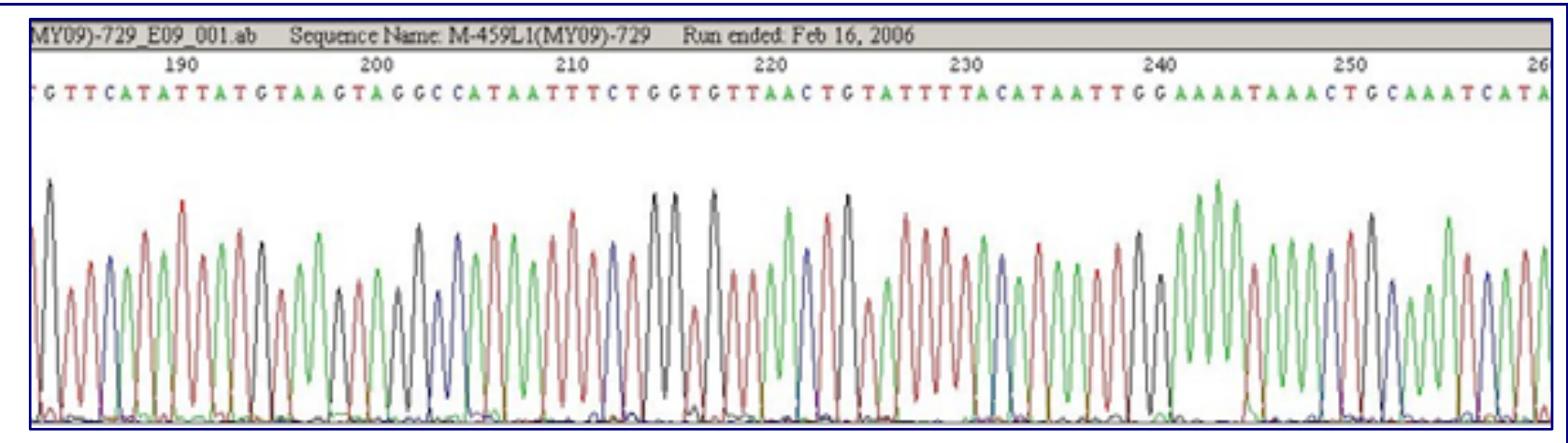

Fig. (6). DNA sequence for type 81-HPV.

crucial for the outcome. Each of the techniques described detects a different range of HPVs and for the common group of HPVs, which are detected by all the techniques, the differences in sensitivity and specificity are variable although they are comparable to the clinical level. The Hybrid Capture technique requires the use of a specific preservative solution and in those cases in which the sample is degraded the reaction does not have the proper specificity. In the same way PCR consensus techniques reduce sensitivity in low quality DNA samples. Specific PCR is less dependent on the DNA quality and allows the analysis of samples stored in paraffin. The best relationship between sensitivity and specificity in hybrid capture is obtained by applying a cut-off level of $1 \mathrm{pg}$ of DNA, however, for sensititivity to be comparable to the clinical level with PCR, a cut-off level of $0.2 \mathrm{pg}$ positivity DNA should be established, with the disadvantage of that this level of cut-off produces false positives, specially in samples with low-risk HPV and high viral load.

As regards methods based on PCR techniques consensus MY09/11 and GP5+/6+ achieve a good correlation in relation to the types detected by both techniques (Kappa $=0.79)$, however, certain viral types are only detected by one of the two techniques. Undoubtedly, the combination of some of these techniques with the detection of the specific types which are more involved in carcinogenesis, such as HPV16 and HPV18, generates some level of sensitivity and specificity, which are optimal at a clinical level [43].

\section{ANALYSIS OF THE PRESENCE OF ONCOGENIC PROTEINS}

In view of the aforementioned descriptions in the previous sections, it seems logical to think that the detection of oncogenic protein levels constitutes one of the best indicators of transformation capacity in the cervical samples. We must take into account a series of general concepts and limitations before assessing the adequacy of protein analysis compared to the determination of viral DNA or RNA (Fig. 7).

The amount of oncogenic protein transcribed in vivo in the cell, is dependent on many factors

- $\quad$ Viral type

- $\quad$ Amount of virus (viral load)
- the rate of transcription of RNA

- Presence of transcriptional modulators (corticoids, hormones, etc. )

- Integrity of the DNA

- Activation or inactivation of promoters and regulators.

The half-life ex vivo of the protein, or the RNA that transcribes it, can be very limited, substantially modifying results in terms of management and the quality of the sample.

The clinical utility of the determination of the presence of HPV, depends not only on the complexity of the study, but also bases its effectiveness on the availability, reproducibility and low cost of the method, which allows it to be used for routine tracking. For this reason, and given the great stability of DNA and the power of the detection methods, most of the diagnosis strategies for HPV, of proven effectiveness, use it as a target for the characterization of the infection (PCR, hybrid capture).

At this point, we must ask a series of questions:

1. What is dependent upon the rate of expression of a specific type of HR-HPV?

2. Does the presence of viral DNA in HR-HPV mean that the oncogenic proteins are expressing themselves?

3. Is the expression of these proteins dependent upon of the amount of virus present in the sample?

We should bear in mind that a negative response to these three questions invalidates the capacity of HR-HPV detection, as a predictor of risk of cervical injury, given that the presence of a high-risk viral type, regardless of the amount or rate of infection detected, does not necessarily mean the expression of the proteins capable of affecting the cellular cycle and of causing cellular immortalisation, and thus, its value for establishing risk groups.

In response to the first two issues, there have been a multitude of studies on gene expression, which show that the production of E6 and E7 oncogenic proteins, in those cases where the virus remains complete i.e. episomal, is invariably preserved regardless of the viral type that codified it and that it is modified only in response to modulator signs from its 

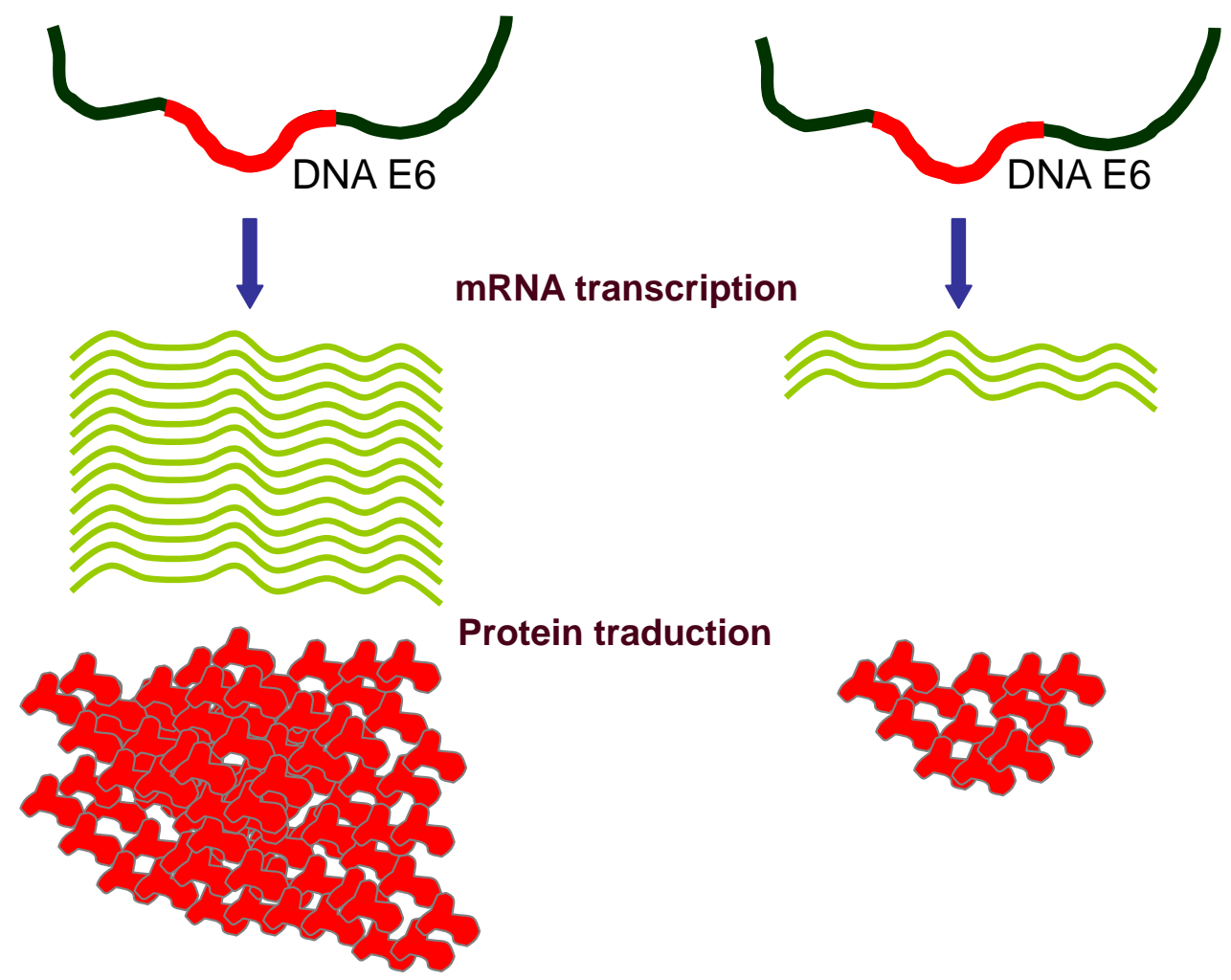

Fig. (7). The translation process of viral protein passes through the transcription of viral DNA to a messenger RNA. The control of this transcription depends upon the final amount of protein transcribed, with a single viral DNA being able to replicate huge amounts of itself.

promoters depending on the stage of infection. In this way, except for discrete exceptions, incomplete form of the virus expresses constant amounts of E6 and E7 once the infection is becoming persistent. This is very different from the case, in which the DNA of HPV becomes integrated, since in this circumstance, the disappearance of the E2 HR-HPV region, acts on the E6 and E7 promoters, positively deregulating and increasing the production of messenger RNA and the transcription of this into oncogenic protein.

We are now in a position to say that the amount of oncogenic protein can be reliably estimated analysing the amount of virus present in each cellular unit and the state of integration i.e. evaluating the viral load of individual cells and the episomal or integrated state of HR-HPV.

\section{ESTIMATION OF VIRAL LOAD: TOTAL LOAD VS RELATIVE LOAD}

Performing an analysis of the bibliography on viral load, we are faced with highly disparate allegations with regards to its clinical value. There are works, with impeccable methodology, linking the increases in the viral load with increases in the degree of cervical injury and on the contrary, there are works with the same methodological quality that demonstrate the total lack of association. Here is where we must clarify the different meanings of viral load on the basis of distribution of the viremia.

By Total Viral Load, we understand the number of viral particles present in the biological sample under study. It is easy to understand that this directly depends on four factors:
- Cellularity of the samples (type of device used and exfoliation used)

- $\quad$ Surface distribution of the injury

- Infection rate per cell

- Conservation of the sample (degradation of DNA, the presence of inhibitors, etc.)

We refer to Relative Viral Load when the value of the total load is corrected as a function of the number of cells present in the samples, valuing the latter, depending on the number of constitutive DNA molecules used as a control and which are necessarily copies of a single cell. The values of the relative viral load will not be, therefore, influenced by the cellularity of the samples used (Fig. 8).

\section{VIRAL INTEGRATION}

Another point of dispute, regarding the transcription of neoplastic lesions, is that concerning the need for viral integration to produce immortalisation of infected cells. Although it has been demonstrated that certain cell lines derived from established tumours presented complete integration of virus genome in the host, this does not demonstrate the need for such an event to occur for the emergence of tumoural phenotypes, but that it could well be an accessory to other characteristics that give those cell lines the consideration of being clonal (Figs. 9, 10).

It is well demonstrated, in support of the previous assumptions, that there is a percentage of tumoural lesions, which is not negligible, in which neither integration has been proven nor coexistence of episomal and integrated forms. 


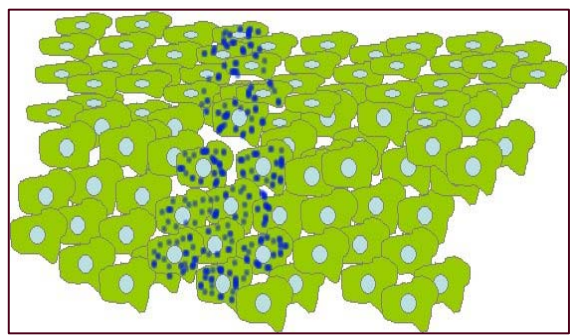

Total viral load 116.000 copies

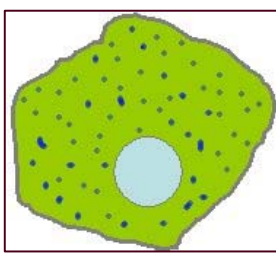

Relative load: 1600 virus/cell

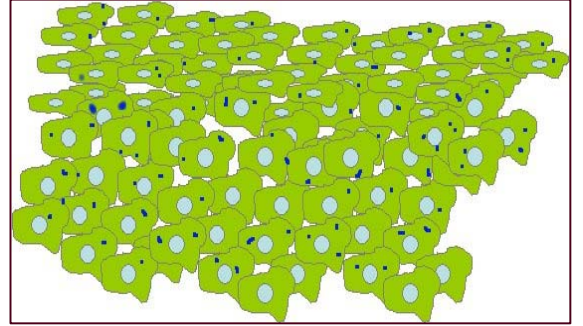

Total viral load 116.000 copies

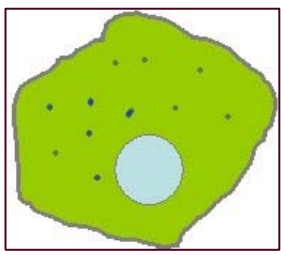

Relative load:

50 virus/cell

Fig. (8). Total viral load and relative viral load. Distribution in the viremia.

\section{Episomal HPV}
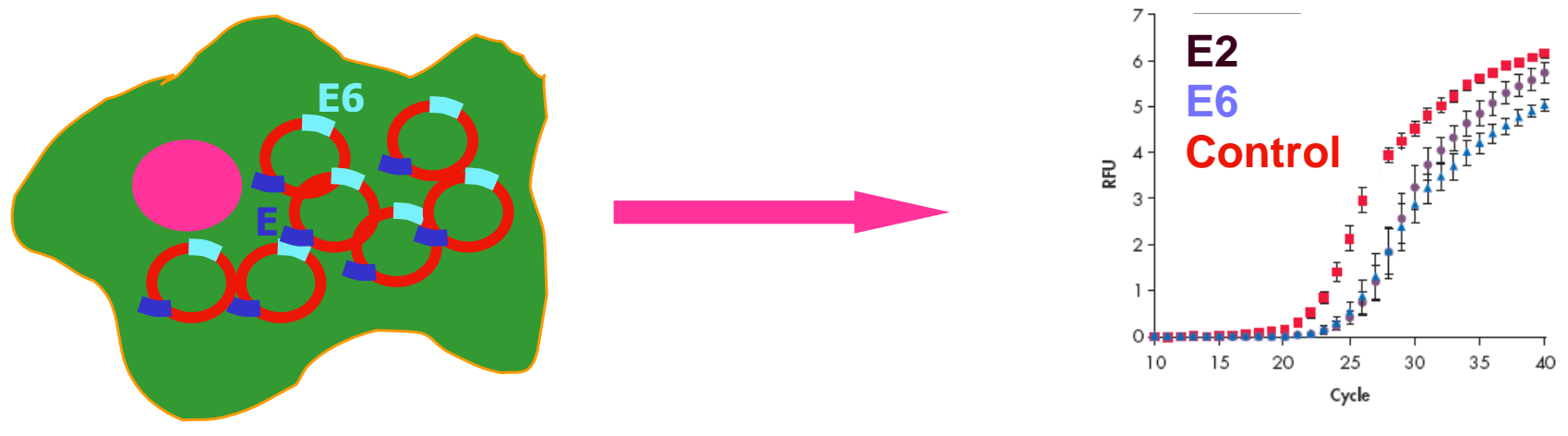

\section{Ratio E6/E2 1}

Fig. (9). Episomal virus. All viral regions are present.

In response to the aforementioned descriptions, in relation to the oncogenic proteins, it is logical to assume that the final requirements of the transformation process are defined by an effective blockage of the cell cycle proteins. This blockage can be derived either from a large amount of virus, which express quantities of basal oncoprotein or from a small proportion of them which show high rates of the same, either due to integration processes or independent of it. In conclusion we can say that viral integration generally causes a persistent state of oncoprotein expression, but that in this same state there may be the combination of factors not related to integration, making it a sufficient cause, but not necessary, to give the cells transformation characteristics.

One of the technical difficulties for the evaluation of the viral integration lies in the need to assess the disappearance, 


\section{Viral integration}

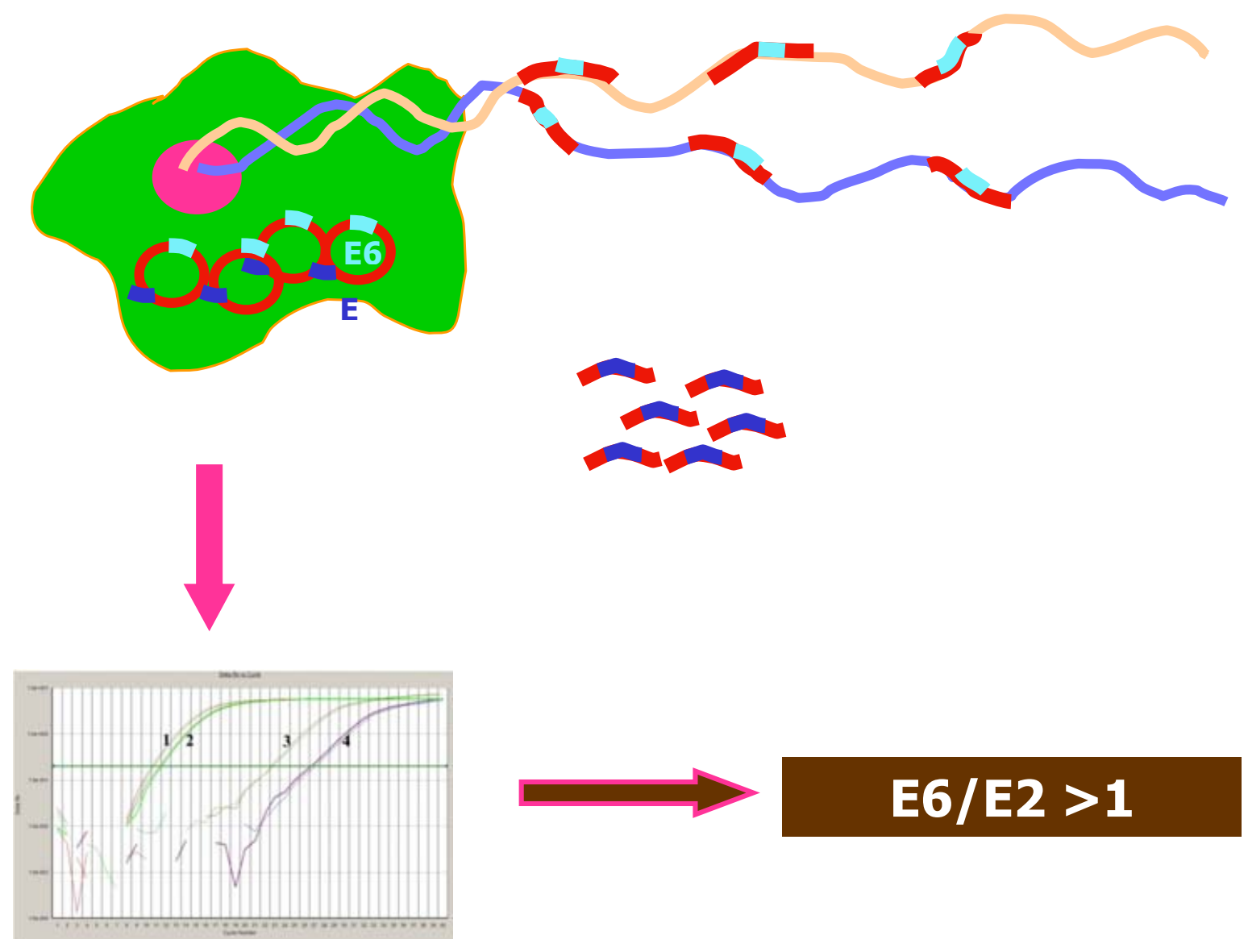

Fig. (10). Integrated virus. Certain viral regions, preferably E2, disappear due to fragmentation at the time of integration finding themselves, in this way, diminished in relation to regions, which are preserved as E6.

by excision, of viral E2 ORF. This gene is responsible for acting on the p97 and p105 promoters which maintain the expression of E6 and E7 repressed. On losing E2, due to integration in the cellular genome, the repressor effect is not exercised with the consequent overexpression of oncoproteins. Given that the PCR method, used to assess the presence of E2, is an exclusively qualitative technique, it requires complete disappearance of E2 in all cells as, otherwise, the coexistence of episomal virus, with intact E2 regions, would masque the integrated forms due to their amplification.

\section{TECHNIQUES FOR DETECTION OF VIRAL LOAD AND INTEGRATION}

The detection of viral DNA can be carried out using different molecular biology techniques, however, two fundamental methods have become references for diagnosis. The first of them is detection, in solution, of viral DNA hybrids with complementary synthetic RNA probes, which are later revealed with fluorescence. This is the so-called hybrid capture and its commercial version Hybrid Capture $\mathrm{II}^{\circledR}$ is the most widespread early diagnosis technique and the only diagnostic technique approved by the FDA. The second of the techniques, which is also widespread, but on a more experimental basis and with multiple implementation formats, is PCR.

The technique of hybrid capture allows the detection of the HPVs by risk groups (high and low-risk), as well as allowing us to estimate the total viral load present in the sample (necessarily cells in suspension). Conventional PCR, which is so variable on the basis of the primers or primers used, allows the detection of all viral types, high and lowrisk, and their subsequent specific typing.

Until the appearance of the real time PCR, the determination of the viral load was very semi-quantitative based on densitometric methods. The state of integration was evaluated by amplification or non-amplification of the common E2 breakage region, with the problems described above, derived from the coexistence of pure forms integrated with episomal forms. Other techniques, such as the Southern Blot, able to alleviate these shortcomings, lack clinical validity due to the requirements of excessive DNA, time and cost [44]. 


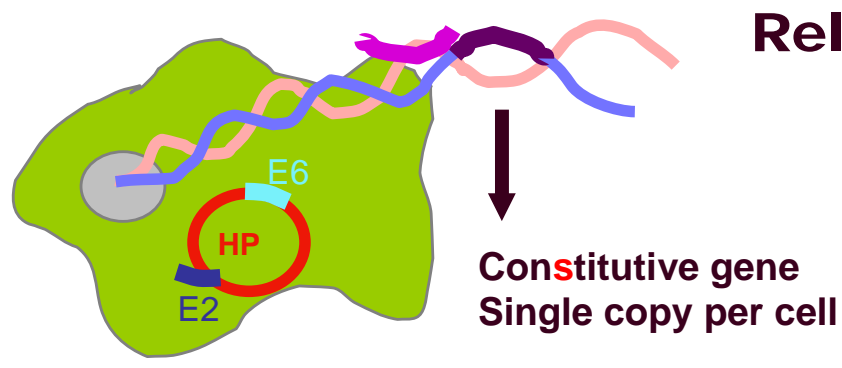

\section{Relative load estimation}

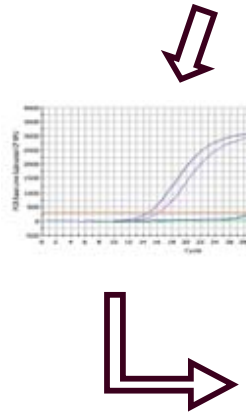

16.000 cells

165.000 HPVs
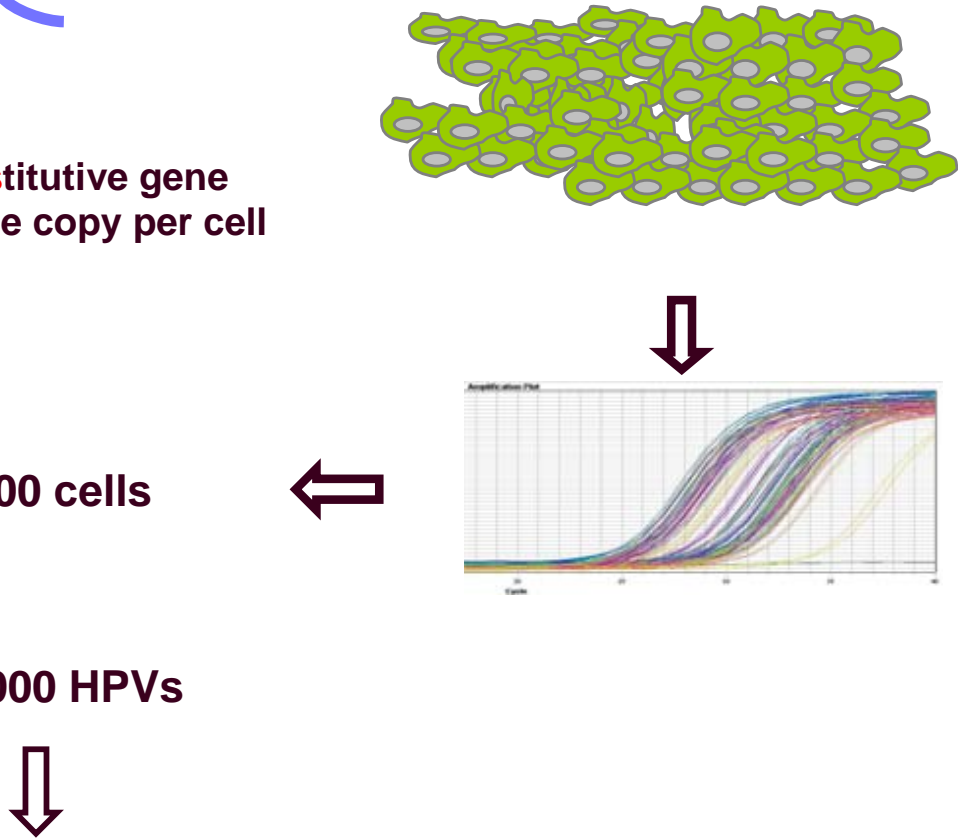

10,3 HPV / Cell

Fig. (11). Relative viral load is estimated as a ratio between a single copy constitutive gene and the number of copies of HPV obtained by amplification of a viral gene using quantitative Real Time PCR.

\section{REAL-TIME PCR}

The main difference between conventional PCR and Real Time PCR lies in the ability of the latter to assign real quantitative values to the amplified value. Through the use of specific probes marked with fluorochromes $\left(\operatorname{Taqman}^{\circledR}\right.$, Scorpions), the values of excitement luminance, cycle to cycle, after the application of laser light are measured and they are quantified with a CCD camera. The increases or decreases in luminance levels allow regression analysis and the definition of a reference line, from where we can extrapolate the initial quantitative values for each gene studied. The method, although complex, is extremely reliable and compares, individually, the quantities of a particular viral gene, in relation to a constitutive cellular gene or to another viral gene region. The determination of the total load is given by the analysis of a particular conserved region of the specific HPV under study. The relative load is obtained from the ratio between the total load and the number of cells, estimating the latter from the quantification of a constitutive cellular gene (always present) of a single copy (a gene copy=a cell) $($ Fig. 11).

The determination of the integration state is similarly given through the analysis of the proportion of E6 and E7 with the gene susceptible to E2 loss. We should bear in mind that in the unfragmented virus, for each copy of the E6-7 gene there should be a copy of E2. Changes to this equilibrium inform us of the viral state: Episomal if E6-
$7=\mathrm{E} 2$, total Integration if $\mathrm{E} 2=0$, and coexistence of episomal and integrated forms if E6-7> E2 [45, 46].

We have reviewed the epidemiology of HPV, as well as its pathogenesis, global prevalence, infection magnitude, and risk factors. The concept of viral clearance and persistence was described. We have appreciated the pre-established association between HPV infections and certain types of cancer: cervical, vulvar, vaginal, penile, and oropharyngeal, as well as with other types of pathologies, such as recurrent respiratory papillomatosis and genital warts (condylomata acuminata). We provide new information about other pathologies associated with HPV. And furthermore, we would like to emphasise that the increasing incidence of HPV infection and genital warts highlights the need for an effective strategy for the management of this disease. Finally, immunisation holds the promise of reducing the overall load of clinical HPV-related diseases [47].

\section{REFERENCES}

[1] Bernard N, Fields MD. Virology. New York: Reven Press 1990.

[2] Zur Hausen H. Condylomata acuminata and human genital cancer. Cancer Res 1976; 36: 794.

[3] Torroella-Kouri M, Morsberger, S, Carrillo A, et al. HPV prevalence among mexican women with neoplastic and normal cervixes. Gynecol Oncol 1998; 70: 115-20.

[4] Vasconcellos M, Aranda C, Ruiz Moreno JA, Paz E. Búsqueda, detección y control del virus del papiloma humano (VPH). Ginecol Obstet 1992; 60: 37-41.

[5] Fenner F, Backmann PA, Gibbs EPJ, Murphy FA, Studdert MJ, White DO. Virologia Veterinaria. Mexico: Acribia 1992; pp. 331-9. 
[6] Munoz N, Bosch FX, de Sanjosé S, et al. Epidemiologic classification of human papillomavirus types associated with cervical cancer. N Engl J Med 2003; 348: 518-27.

[7] Cole ST, Danos O. Nucleotide sequence and comparative analysis of the human papillomavirus type 18 genome. Phylogeny of papillomaviruses and repeated structure of the E6 and E7 gene products. J Mol Biol 1987; 193: 599-608.

[8] Hubbert NL, Sedman SA, Schiller JT. Human papillomavirus type 16 E6 increases the degradation rate of p53 in human keratinocytes. J Virol 1992; 66: 6237-41.

[9] Hoffmann R, Hirt B, Bechtold V, Beard P, Raj K. Different modes of human papillomavirus DNA replication during maintenance. $\mathrm{J}$ Virol 2006; 80: 4431-9.

[10] Bousarghin L, Touze A, Sizaret PY, Coursaget P. Human papillomavirus types 16,31 , and 58 use different endocytosis pathways to enter cells. J Virol 2003; 77: 3846-50.

[11] Day PM, Lowy DR, Schiller JT. Papillomaviruses infect cells via a clathrin-dependent pathway. Virology 2003; 307: 1-11.

[12] Smith JL, Campos SK, Ozbun MA. Human papillomavirus type 31 uses a caveolin 1- and dynamin 2-mediated entry pathway for infection of human keratinocytes. J Virol 2007; 81: 9922-31.

[13] Arends MJ, AH Wyllie, Bird CC. Papillomavirus and human cancer. Human Pathol 1990; 21: 686-98.

[14] Day T, Vaziri C. HPV E6 oncoprotein prevents recovery of stalled replication forks independently of p53 degradation. Cell Cycle 2009; 8: 2138.

[15] Gariglio P, Benitez-Bribiesca L, Berumen J, Alcocer JM, ReyesTamez, Madrid V. Theraeputic uterine-cervix cancer vaccines in humans. Arch Med Res 1998; 29: 279-84.

[16] Ling Peh W, Middleton K, Christensen N, et al. Life cycle heterogeneity in animal models of human papillomavirusassociated disease. J Virol 2002; 76: 10401-16.

[17] Frattini MG, Laimins LM. Binding of the human papillomavirus E1 origen-recognition protein is regulated through complex formation with the E2 enhancer- binding protein. Proc Natl Acad Sci USA 1994; 91: 12398-402.

[18] Doorbar J, Elston RC, Napthine S, et al. The E1-E4 Protein of human papillomavirus type 16 associates with a putative RNA helicase through sequences in its c terminus. J Virol 2000; 74: 10081-95.

[19] Nakahara T, Nishimura A, Tanaka M, Ueno T, Ishimoto A, Sakai H. Modulation of the cell division cycle by human papillomavirus type 18 E4. J Virol 2002; 76: 10914-20.

[20] Zur Hausen H. Papillomaviruses causing cancer: evasion from host-cell control in early events in carcinogenesis. J Natl Cancer Inst 2000; 92: 690-8.

[21] Lu Z, Hu X, Li Y, et al. Human papillomavirus 16 E6 oncoprotein interferences with insulin signaling pathway by binding to tuberin. J Biol Chem 2004; 279: 35664-370.

[22] Middleton K, Peh W, Southern S, et al. Organization of human papillomavirus productive cycle during neoplastic progression provides a basis for selection of diagnostic markers. J Virol 2003; 77: 10186-201.

[23] Herbsleb M, Knudsen UB, Orntoft TF, et al. Telomerase activity, MIB-1, PCNA, HPV 16 and p53 as diagnostic markers for cervical intraepithelial neoplasia. APMIS 2001; 109: 607-17.

[24] Deligeoroglou E, Christopoulos P, Aravantinos L, Papadias K. Human papilloma virus molecular profile and mechanisms of cancerogenesis: a review. Eur J Gynaecol Oncol 2009; 30: 128-32.

[25] Baritaki S, Sifakis S, Huerta-Yepez S, et al. Overexpression of VEGF and TGF-betal mRNA in Pap smears correlates with progression of cervical intraepithelial neoplasia to cancer: implication of YY1 in cervical tumorigenesis and HPV infection. Int J Oncol 2007; 31: 69-79.

[26] Chen W, Li F, Mead L, et al. Human papillomavirus causes an angiogenic switch in keratinocytes which is sufficient to alter endothelial cell behavior. Virology 2007; 367: 168-74.
[27] Insinga RP, Dasbach EJ, Elbasha EH, Liaw KL, Barr E. Progression and regression of incident cervical HPV 6,11,16 and 18 infections in young women. Infect Agent Cancer 2007; 2: 15.

[28] Wooldridge TR, Laimins LA. Regulation of human papillomavirus type 31 gene expression during the differentiation-dependent life cycle through histone modifications and transcription factor binding. Virology 2008; 374: 371-80.

[29] Kjaer SK, Tran TN, Sparen P, et al. The burden of genital warts: A study of nearly 70.000 women from the general population in the 4 Nordic Countries. J Infect Dis 2007; 196: 1447 -54.

[30] Castellsagué X, Cohet C, Puig-Tintoré LM, et al. Epidemiology and cost of treatment of genital warts in Spain. Eur J Public Health 2009; 19: 106-10.

[31] Bovicelli A, Bristow RE, Montz FJ. HPV testing: where are we now? Anticancer Res 2000; 20: 4673-80.

[32] Rodríguez-Cerdeira C. Cáncer de vulva. MAS Dermatol 2008; 4 : 26-32.

[33] Rodriguez-Cerdeira C, Rodríguez Cerdeira MC. Síntesis de controversias en Venerelogia. En: Olmos Acebes L. La consulta de ETS (tomo 2). Tréboly comunicación: Madrid 2005; 62-7.

[34] Rodríguez Cerdeira C, Carpintero Feijoo Y, Alcántara Cáceres R, Vilata Corell JJ. Sífilis adquirida. En: Vilata Corell JJ. Venereología: aspectos epidemiológicos y clínicos de las infecciones transmitidas por vía sexual. Madrid: Aula Médica 2005; pp. 51-61.

[35] Syrjänen y Syrjänen. Papillomavirus infections in human pathology. Chichester: Wiley \& Sons 2000; pp. 11-46.

[36] Burchell AN, Winer RL, De Sanjosé S, Franco E. Epidemiology and transmission dynamics of genital HPV infection. Vaccine 2006; 24: S3/52 -61.

[37] Baseman JG, Koutsky LA. The epidemiology of human papillomavirus infections. J Clin Virol 2005; 1: S16-24.

[38] Rodríguez-Cerdeira C. Tumores malignos. In: Guerra Tapia A, Ed. Patología genital masculina no ITS. Monografías de Dermatología. Madrid: Grupo Aula Médica 2008; 21: pp. 393-401.

[39] Kang WD, Kim CH, Cho MK, et al. Comparison of the hybrid capture II assay with the human papillomavirus DNA chip test for the detection of high-grade cervical lesions. Int J Gynecol Cancer 2009; 19: 924-8.

[40] de Araujo MR, De Marco L, Santos CF, et al. GP5+/6+ SYBR Green methodology for simultaneous screening and quantification of human papillomavirus. J Clin Virol 2009; 45: 90-5.

[41] Baseman JG, Koutsky, LA. The epidemiology of human papillomavirus infections. J Clin Virol 2005; 1: S16-24.

[42] Jacobs MV, Snijders PJ, van den Brule AJ, Helmerhorst TJ, Meijer CJ, Walboomers JM. A general primer GP5+/GP6(+)-mediated PCR-enzyme immunoassay method for rapid detection of 14 highrisk and 6 low-risk human papillomavirus genotypes in cervical scrapings. J Clin Microbiol 1997; 35: 791-5.

[43] Roda Husman AM, Walboomers JM, van den Brule AJ, Meijer CJ, Snijders PJ. The use of general primers GP5 and GP6 elongated at their 3 ' ends with adjacent highly conserved sequences improves human papillomavirus detection by PCR. J Gene Virol 1995; 76: 1057-62.

[44] Boulet GA, Horvath CA, Berghmans S, Bogers J. Human papillomavirus in cervical cancer screening: important role as biomarker. Cancer Epidemiol Biomarkers Prev 2008; 17: 810-7.

[45] Leo E, Venturoli S, Cricca M, Musiani M, Zerbini M. Highthroughput two-step LNA real time PCR assay for the quantitative detection and genotyping of HPV prognostic-risk groups. J Clin Virol 2009; 45: 304-10.

[46] Iftner T, Germ L, Swoyer R, et al. Study comparing human papillomavirus (HPV) real-time multiplex PCR and Hybrid Capture II INNO-LiPA v2 HPV genotyping PCR assays. J Clin Microbiol 2009; 47: 2106-13.

[47] Rodríguez-Cerdeira C, Alba A, Vilata JJ. Desarrollo de nuevas vacunas contra el virus del papiloma humano. Piel 2007; 22: 51-3. 